\title{
Crimes Against Humanity and Hostes Generis Humani
}

\author{
Antony Duff
}

\section{Hostis generis humani: substance and jurisdiction}

The bulk of David Luban's paper, 'The Enemy of All Humanity,' consists in a wonderfully rich, nuanced genealogy of the idea of 'hostis generis humani' - the enemy of all humanity or, as Luban notes it can also be expressed, 'communis hostis omnium,' the common enemy of all. That genealogy shows, inter alia, how inadequate and over-simplified some modern readings of hostis generis humani are, including my own: ${ }^{1}$ but I am not competent to discuss it here - all I can do is admire and learn. Instead, I will focus on the final part of Luban's paper, in which he offers us a contemporary analysis of hostis generis humani, to show how it can illuminate the character of genocide and crimes against humanity as core crimes in international criminal law, and to show how bodies like the International Criminal Court can properly claim jurisdiction over them.

The hostis generis humani need not, Luban shows, be understood or treated as an outlaw: as a monster who is excluded - who has excluded himself - from human community, and who can therefore simply be killed or 'exterminated.' Rather, we can see the hostis generis humani as one who is still a member of the human community, ${ }^{2}$ still in that sense a fellow, and part of the point of international trials at tribunals like the ICC is precisely to make that clear: '[w]e insist that the enemy of all humanity is, in fact, a member of humanity and accountable to humanity.' ${ }^{3}$ In doing this, we also help to create that community - that 'moral community' - of humanity to which the hostis generis humani is to be accountable. It is worth emphasizing here just how ambitious, how demanding, this approach is - which is not to say that it is anything less than humanly admirable. The idea that 'we' should aspire to create a moral community of which every human being is a recognized and valued member, and that such a community can be said already to exist in virtue of that aspiration, is itself a plausible, and ambitious, one: it is perhaps evidenced most clearly in international efforts at various kinds of humanitarian assistance and support, as motivated by the thought that this is what we

1 See Antony Duff, 'Authority and Responsibility in International Criminal Law,' in The Philosophy of International Law, eds. Samantha Besson and John Tasioulas (Oxford: Oxford University Press, 2010), 589.

2 Though we will see in what follows that the identity of this 'we,' as well as the identity of this community, are problematic.

3 David Luban, 'The Enemy of All Humanity,' Netherlands Journal of Legal Philosophy 2 (2018): 33. 
owe to others simply as our fellow human beings. ${ }^{4}$ But the idea that membership of the human community is unconditional, that not even the commission of the most terrible wrongs, of 'unimaginable atrocities that deeply shock the conscience of humanity, ${ }^{5}$ can exclude a person from it, is (to put it mildly) a challenging one: we - a 'we' that must include the victims or survivors of such wrongs - must still try to see and to treat their perpetrators as fellow members of the human community that we aspire to build. ${ }^{6}$ I will not discuss this point further here, save to note that once we think about the demandingness of this reading of hostis generis humani, we will also see how tempting a more exclusionary reading is: how tempting it must be to see, how hard it must be for those subjected to or confronted by such atrocities not to see, their perpetrators as moral outlaws who by their deeds exclude themselves from the moral community of human beings. ${ }^{7}$ I share Luban's hope that we can collectively resist that temptation; but we must also recognize that it is one that is morally hard to resist.

However, my concern here is with Luban's account of the substantive and the jurisdictional dimensions of the hostis generis humani: that is, of the distinctive character of the wrongs whose commission renders the perpetrator hostis generis humani, and of what gives such international tribunals as the ICC proper jurisdiction over such wrongs.

The paradigm wrongs here are genocide and 'crimes against humanity': since genocide is, in substance if not in its legal classification by the Rome Statute, ${ }^{8}$ a crime against humanity, we can for simplicity's sake talk just of crimes against humanity. Crimes against humanity can, Luban argues, be understood as crimes against a central aspect of our humanity - against 'our nature as political beings. ${ }^{9}$ For human beings are social, political beings: we can live human lives only in political communities, only under the protective aegis of a state. (More precisely, two claims are made here: first, that human life is possible only in political communi-

4 This is to treat 'fellow human being' as a bedrock moral concept - whereas Kantians would say that the basic moral category must be that of rational agent, and Benthamites would say that it must be that of sentient being (a being susceptible to pleasure and pain): for a defence of this kind of approach, see Raimond Gaita, Good and Evil: An Absolute Conception, 2nd ed. (London: Routledge, 2004), ch. 3.

5 Rome Statute of the International Criminal Court, Preamble.

6 Compare Gaita, Good and Evil, 2 on the idea that 'even the most terrible evil-doers' are 'owed unconditional respect [as human beings], meaning, not that they are deserving of esteem, but that they are owed a kind of respect which is not conditional upon what they have done and which cannot be forfeited.'

7 Compare P.L. Berger, A Rumour of Angels (London: Penguin, 1970), 87, on 'deeds that demand not only condemnation, but damnation in the full religious meaning of the word - that is, the doer not only puts himself outside the community of men; he also separates himself in a final way from a moral order that transcends the human community'; see also C.W. Morris, 'Punishment and Loss of Moral Standing,' Canadian Journal of Philosophy 21 (1991): 53, on the 'loss of moral standing' that flows from crimes such as those of 'contract killers, war criminals, tyrants, and certain terrorists.'

8 The Rome Statute distinguishes 'genocide' (Art. 6) from 'crimes against humanity' (Art. 7): see Luban, 'Enemy of All Humanity,' n. 3.

9 Luban, 'Enemy of All Humanity,' 34. 
ties; and second, that such communities are possible only given the institutional apparatus of a state. Anarchists deny the second of these claims: but I cannot pursue that debate here.) It is that aspect of human existence that hostes generis humani attack: '[i]nstead of protecting people who must, necessarily, live in a political community if they are to live at all, they persecute and annihilate them. ${ }^{10}$ There is thus a particularly grievous kind of betrayal involved in those paradigm crimes against humanity that are committed or at least condoned by state or state-like agents: the very organs that are meant to protect their citizens are turned against them - to destroy their civic, and thus their human, lives rather than to protect them.

If this is the distinctive substantive character of 'crimes against humanity,' we can see why international tribunals like the ICC should be able to claim jurisdiction over them - why indeed we should create such tribunals partly for that purpose. For the hostis generis humani claims or aims to exempt himself from the ordinary jurisdiction of domestic criminal law: that is one of the implications of the statist character of his crimes, seen perhaps most clearly (as Luban points out) in the conduct of the tyrant. ${ }^{11}$ By bringing him within the jurisdictional reach of an international tribunal, we thereby deny, and remove, such immunity. ${ }^{12}$ We ensure that he can still be called to appropriate account: called now not to or by his domestic polity, but to and by 'humanity,' as the appropriate moral community that such a calling to account also helps to create.

Luban offers a very plausible reading of the distinctive character of crimes against humanity, of what distinguishes them from other kinds of serious attack on the person: whilst they involve multiple acts of murder, or rape, or torture, acts that could be said to attack the humanity of their victims, ${ }^{13}$ what gives them their character as crimes against humanity is not simply the fact that they involve multiple victims and multiple offenders, but that they also attack the very possibility of political, and thus human, life. He also offers an attractive account of how that character can ground the jurisdictional claims of international criminal tribunals: humanity steps in when local, domestic law fails or is undermined, to ensure that the tyrant or the hostis generis humani cannot exempt himself from accountability. But his jurisdictional argument is still, I think, problematic, as we can see when we ask more carefully who is calling the hostis generis humani to account: who the 'we' are who insist that he must answer for his crimes.

'We' are humanity, understood neither as a mere aggregation of individuals (an aggregation is not a community); nor as a political community, since there is no such thing: ${ }^{14}$ but as a moral community, one that is in the process of being con-

10 Luban, 'Enemy of All Humanity,' 24.

11 See Luban, 'Enemy of All Humanity,' 21-25.

12 In the Preamble to the Rome Statute, the state parties declare their determination 'to put an end to impunity for the perpetrators of these crimes.'

13 See Massimo Renzo, 'Responsibility and Answerability in the Criminal Law,' in The Constitution of the Criminal Law, eds. Antony Duff et al. (Oxford: Oxford University Press, 2013), 209.

See Luban, 'Enemy of All Humanity,' 31. 
structed or constituted. The problem, however, is that this seems to be the wrong kind of community to ground an international criminal law: for (to put the point too crudely) what criminal law depends on, and what it can help to constitute, is a political, not a moral, community. This might seem a misguided or pedantic objection: surely, it might seem, humanity as a (nascent or developing) moral community could use the institutional apparatus of international law and international courts to discharge the moral task of calling such criminals to account, just as it can use other kinds of institutional, political mechanism to pursue the humanitarian moral task of bringing relief to human suffering wherever it is found. But there is, I think, more to this objection than misguided pedantry. To show this, I will comment briefly on, first, the relationship between domestic criminal law and the (re)building of national political community; and second, how we should understand the principle of subsidiarity, under which the ICC has no jurisdiction if ' $\mathrm{t}$ ] he case is being [or has been] investigated or prosecuted by a State which has jurisdiction over it, unless the State is unwilling or unable genuinely to carry out the investigation or prosecution. ${ }^{\text {'15 }}$ Finally, I will suggest that we can resolve this problem by talking of a community not of individual people ('humanity'), but of nations or polities.

\section{Criminal law and the constitution of political community}

Domestic criminal law is part of the political structure of a polity - a political community. It is concerned with wrongdoing - with defining and declaring that set of public wrongs for which those who commit them will be called to formal, public, punitive account through the criminal process; but it is not concerned with all wrongdoing - it is not the moral law, or an agent of the moral law. It is, we can say, properly concerned only with wrongs that impinge on or violate the polity's 'civil order' or 'civil peace': with conduct that violates the values by which the polity defines itself, and that is inconsistent with what its citizens owe to each other as fellow members of that political community. Conduct is thus, in principle, criminalizable if it is disruptive of, or inconsistent with, that civil order; criminal law, as a particular kind of response to such wrongs, helps both to protect and to constitute that order. ${ }^{16}$

It is important to be clear that the order that criminal law protects and partly constitutes is the civil order - not the moral order; the community in whose name and for whose sake it speaks and acts is the political community - not any of the various moral communities to which its citizens will also belong; the relationships that it might aim to restore, through the criminal process, are the civic relationships between the polity's citizens - not the many moral relationships in which they might also stand to each other. A criminal wrong is a wrong that is inherently destructive of, or (in the case of less serious wrongs) inconsistent with, the

15 Rome Statute, Art. 17.

16 For a development and explanation of this conception of (domestic) criminal law, see Antony Duff, The Realm of Criminal Law (Oxford: Oxford University Press, 2018). 
civil order within which the citizens live, or hope to live; by responding appropriately to such wrongs (by declaring them to be public wrongs, by calling their perpetrators to public account) that order can be protected or restored.

Criminal law can also sometimes be part of the process of (re)building political community in the aftermath of serious civil conflict or oppression. When those who are accused or suspected of committing serious wrongs during the conflict, or those who oppressed a people, are called to public account through a criminal process, or through the kind of 'Truth and Reconciliation' process that seeks an accounting for such past wrongs, the aim need not simply be to hold such wrongdoers to account; it can also be to rebuild the political community to which they and those whom they wronged belong, and to which (to whose members) they should answer for what they did. More precisely, the aim might be to rebuild a political community that was real, but that was torn apart by civil conflict; or, as in the aftermath of dictatorships or of other kinds of oppressive regime, to make real a political community that previously existed (if at all) only in name. But it is again important to notice that what is to be (re)built is precisely a political community, a polity of citizens: neither a criminal process, nor a Truth and Reconciliation Commission, can properly or plausibly aim to reconcile the previous combatants, or the oppressors and the oppressed, as friends - only as citizens. ${ }^{17}$ This kind of process can help to rebuild or reconstitute the domestic political community, to restore the recognized authority of its norms, and to repair the relationships that bind its members together as citizens - which is to restore the civil order of the polity.

Now the crimes against humanity on which Luban focuses are also, more dramatically and more radically, destructive of political community: that is why he rightly characterizes them as crimes against 'our nature as political beings. ${ }^{18}$ But the political community that they destroy is the domestic, local community within which they are committed; and that is not the community that could be restored or reconstituted by an international criminal process as Luban portrays it. For such an international process speaks in the voice not of the local polity, but of humanity - of humanity as a moral, not a political community; the norms whose authority the process (re)asserts, and whose very existence it helps to establish, ${ }^{19}$ are thus meant to be universal moral norms, rather than the norms that structure a political community. More precisely, we can say that any viable political community must include (versions of) such norms in its civil order: but an international criminal process that speaks in the voice of a universal moral community

17 I cannot engage here with the vast and ever-growing literature on transitional justice, but I have learned much from Pablo de Greiff, 'Theorizing Transitional Justice,' in Transitional Justice, eds. Melissa S. Williams, Rosemary Nagy, and Jon Elster (NOMOS LI: NYU Press, 2012), 31; Ruti Teitel, Transitional Justice (Oxford: Oxford University Press, 2000); Lucy Allais, 'Restorative Justice, Retributive Justice, and the South African Truth and Reconciliation Commission,' Philosophy \& Public Affairs 39 (2012): 332.

18 Luban, 'Enemy of All Humanity,' 34; see at nn 9-10 above.

19 'By establishing the practice of calling tyrants to account, we create those norms [norms against radical evil] as norms': Luban, 'Enemy of All Humanity,' 33. 
cannot (re)establish such norms as the political norms of a civil order. It might be tempting to say that crimes against humanity 'offend the international public order, ${ }^{, 20}$ which is the public, political order that international criminal trials can help to restore. But that cannot be the public order of a polity to which we all belong as human beings - since there is no such polity: so it remains unclear just what this order is, of whose or what community it is the order, and how it is a public order that 'humanity,' as a moral community, could aim to reconstitute.

I will suggest a way out of this puzzle below, but should first turn to a further question about Luban's account - about how we should understand the principle of subsidiarity.

\section{Subsidiarity and the ICC}

As I noted earlier, the ICC operates under a principle of subsidiarity: it has jurisdiction over a crime only if the state that initially has jurisdiction (typically the state in whose territory it was committed) is unwilling or unable genuinely to carry out the investigation or prosecution' of the crime. ${ }^{21}$ There are, roughly, two ways to understand the normative grounding of this principle.

On one view, it could be described as a principle of efficient delegation. The hostis generis humani is properly answerable to humanity, which suggests that he should ideally be brought to trial before an international tribunal such as the ICC brought to trial not just for the wrongs he committed against his individual victims, but for his attack on the political dimension of human life, and his attempt to exempt himself from the jurisdiction of domestic criminal law. There are obvious reasons, of both principle and practice, why he should in fact be brought to trial before the courts of his local polity, if that is possible: that would respect state sovereignty, and allow the local state to use his trial to help reconstitute the local polity; and, if the local criminal justice system is functioning properly, this is a more efficient way of bringing the hostis generis humani to justice. However, insofar as the hostis generis humani is answerable to humanity, the local courts must now be seen to be speaking and acting in the name not (just) of the local polity, but of all humanity. To that extent, their moral authority is derived from that of the international tribunals which speak explicitly in humanity's voice: it is in effect delegated to them by the international community of humanity.

On the other view, the principle of subsidiarity should be understood as a principle of what we might call second-best substitution. The hostis generis humani should, properly and ideally, answer to the polity within which he committed his crimes: for he should answer to his fellow citizens (including especially those whose citizenship he effectively denied) for the wrongs that he committed

20 Luban, 'Enemy of All Humanity,' 19, quoting Judge Robinson in Prosecutor v Milutinović, Ojdanić, and Sainović, Decision on Motion Challenging Jurisdiction, Case No. IT-99-37-PT, 6 May 2003, $\S 7$.

21 Rome Statute, Art. 17. 
against their civil order; and by thus holding him to account the polity can recreate or reconstitute that civil order. The ICC can claim jurisdiction only when that local polity cannot thus hold him to account for his crimes: cannot, since the state apparatus that is meant to operate as the institutional mechanism through which the polity governs itself and orders its civic life has been corrupted or taken over by the wrongdoers, and is thus unable or unwilling to function as it should. But a trial before an international tribunal cannot achieve the ends that a domestic trial could intelligibly (if not always realistically) aim to achieve: it cannot restore the civil order that the hostis generis humani attacked, or prevent the hostis gaining immunity from his polity's law. It is true that if he is brought to trial before an international court, he does not secure impunity or immunity altogether, since he is still called to account. But impunity is always relational: that is, it is always impunity from some specifiable kind of liability, which is itself always relational; I am liable to certain kinds of consequence, imposed by a specifiable body that has the standing to hold me liable. The hostis generis humani seeks, and secures, impunity from liability under his own polity's laws, impunity from being held liable by and answerable to his own fellow citizens; what he faces is liability under a different system of law, and to the other members of a different community - the moral community of humanity.

This shows why, on this second view, the ICC constitutes a kind of second-best substitution: for it cannot achieve the proper aim of bringing the hostis generis humani to answer to his fellow citizens for his crimes against their civil order; it brings him to answer to a different community, and for a different dimension of his wrongdoing - an offence against 'international public order.' An admittedly imperfect analogy might help to clarify this point. When a child's parents cannot or will not take proper care of her, others may intervene: the state, the local authority, might take the child 'into care.' Sometimes, if the child is lucky, that care might become a kind of parental care, if she is fostered and then adopted by people who become, in social and emotional although of course not in biological terms, her parents; but too often she remains 'in care' in a children's home. She is cared for, and we might say (putting it loosely) that the state now provides the care that her parents failed to provide: but if we take family and family relationships seriously, ${ }^{22}$ that is not strictly true. For what the child really, properly, needs is parental care - care from her own parents; and however supportive the care provided by a children's home might be, it necessarily cannot be parental care. In that sense, care provided by the state is inevitably a second-best care: it substitutes, crucially but imperfectly, for the parental care that the child should have received. Analogously, I am suggesting, on this view of subsidiarity the ICC is a second-best substitute for the domestic accountability to which the hostis generis humani ought properly to be held.

The second of these views seems more plausible, as giving the local polity, within which the hostis generis humani committed his wrongs, principled jurisdictional

22 We need not explore the nuances or grounds of this protasis here, or embroil ourselves in the difficult question of the normative significance (if any) of biological parenthood. 
priority; and it fits better with Luban's account of the distinctive character of his wrongs, as including an attempt to escape or to exempt himself from the jurisdictional authority of the polity's laws: for that implies that he should, ideally and properly, answer in and to that polity. On either view, however, there seems to be a mismatch, or a dissonance, between the voice of the ICC and that of the domestic courts who are supposed, under the principle of subsidiarity, to have primary or initial jurisdiction over the crimes of the hostis generis humani. For the domestic voice is a civic voice, the voice of the polity speaking through its laws, and speaking about the violation of its civil order. The voice of the ICC, however, is as Luban portrays it a moral voice - the voice of the moral community of humanity to which all human beings belong, not as citizens of a polity, but simply as moral beings; but it is meant to speak about violations not just of moral norms, but of an 'international public order.' The 'we' who call wrongdoers to account in a domestic criminal court are citizens, speaking as citizens, while the 'we' who call him to account in an international court, the 'we' in whose name the court supposedly speaks and acts, are moral agents, members of a moral community: but yet the court's voice is meant to be the voice of law, since it is a legal institution.

Perhaps I am making too much of this supposed mismatch or dissonance; but I do think there is a problem here, in understanding the normative foundations of tribunals such as the ICC, the character of the community whose law the ICC is to apply and to whose members defendants in the court are supposed to be answerable, and the relationship between the ICC and the domestic courts to which it is 'subsidiary.' I also think, however, that it is a problem that can be solved, by an adjustment to Luban's account: an adjustment that preserves his insight into the distinctive character of the wrongs whose commission turns a perpetrator into a hostis generis humani, and into the jurisdictional issue that such wrongs raise (since they involve what might be a successful attempt to escape the effective jurisdiction of the domestic law and its courts); but that avoids the (to my mind problematic) appeal to a moral community of humanity to solve that problem. The solution involves an initially simple modification: from talking of a community of humanity (a community composed of individual human beings) to talking of a community of nations.

\section{A community of nations}

The Parties to the Rome Statute, '[r] eaffirming the Purposes and Principles of the Charter of the United Nations,' determined 'to establish an independent permanent International Criminal Court in relationship with the United Nations system, with jurisdiction over the most serious crimes of concern to the international community as a whole.'23 If that 'international community' is the community by and to which those who commit such crimes are to be accountable, it is on Luban's account the moral community of humanity, of which all human beings are members as individuals. But is that the right way to understand 'the interna- 
tional community' in this context? A suggestion that it is not might be found in the fact that the Preamble to the Rome Statute starts by talking of 'peoples' (not of 'people' or 'persons') who are 'united by common bonds'; and a stronger suggestion is found in the relationship of the ICC to the United Nations, whose Charter helps to determine the definition of the crime of aggression, ${ }^{24}$ and whose Security Council can refer cases to the ICC. ${ }^{25}$ For this suggests that the relevant international community is composed, not of individual people (human beings), but precisely of nations, ${ }^{26}$ which work together to form, to build, a United Nations; and that the 'international public order' is the order, the ordering, of that community of nations. We can plausibly talk of such a community (recognizing that it is, like so many political and moral communities, a matter more of aspiration than of established fact); we can see the United Nations, along with other international institutions, including the ICC, as attempts to construct, to give institutional form and force to, such a community. ${ }^{27}$

How could this help our understanding of the principled grounds for the jurisdiction of such international tribunals as the ICC? It suggests, first, a different account of the 'we' who now call the hostis generis humani to account, and in whose name and voice the ICC claims to speak: for that voice is not now the collective moral voice of all human beings, but the political voice of this would-be community of nations. The 'States Parties' to the Rome Statute, who declare their determination 'to put an end to impunity for the perpetrators of these crimes,' and 'to establish an independent permanent International Criminal Court' to have jurisdiction over them, ${ }^{28}$ act not for humanity as a moral community, or for the individual human beings who might form such a moral community, but for the polities of which the States Parties are the institutional manifestations, and thus also for the citizens of those polities. ${ }^{29}$

25 Rome Statute, Arts. 13b, 15 ter. See also Art. 2: "The Court shall be brought into relationship with the United Nations through an agreement to be approved by the Assembly of States Parties to this Statute and thereafter concluded by the President of the Court on its behalf.'

26 A community of nations, or of polities, rather than of states (contrast M. Cherif Bassiouni and Edward M. Wise, Aut Dedere Aut Judicare: The Duty to Extradite or Prosecute in International Law [Dordrecht: Nijhoff, 1995], 31-36), because political community is constituted by a nation or polity, of which the state is (should be) the institutional manifestation.

27 Some might think it naïve or over-optimistic to see the UN and the ICC even as genuine attempts to build such a community of nations, and it is admittedly often depressingly hard to discern such an aspiration in their actual operations - as distinct from their rhetoric; but we can still take the rhetoric seriously, as expressing aspirations by which such institutions ought to be guided, and in whose light their operations can be criticized.

28 Rome Statute, Preamble.

29 Compare Raimond Gaita, 'Literature, Genocide and the Philosophy of International Law,' in Crime, Punishment, and Responsibility, eds. Rowan Cruft, Matthew H. Kramer, and Mark R. Reiff (Oxford: Oxford University Press, 2011) 122, 139, on humanity as 'a constituency [not] of moral agents, nor of human beings, but of human beings as citizens in the plurality of nations that comprise the community of nations.' 
Now a community of nations will plausibly have to share some conception not only of what its members owe to each other, of how they should behave towards each other, but also of how a nation should treat its own members (this is also a conception of what a nation is, as a particular form of human association). This at once raises the familiar question of when, if ever, a nation or the community of nations can permissibly intervene in the 'internal' affairs of another nation, to prevent the gross mistreatment of its citizens - when, if ever, it is legitimate to 'pierce' a nation's sovereignty; ${ }^{30}$ and whilst the operations of the ICC do not involve any material intrusion into or invasion of a nation's territory, they do involve a jurisdictional interference in the sense that the ICC can claim the right to try a person for crimes that are (on the view suggested in the previous section) properly the business of the nation within which they were committed. The local polity has the authority, and the responsibility, to hold to account the perpetrators of crimes against humanity committed within its territory; the ICC 'interferes' to claim such authority for itself if the local polity cannot or will not exercise it. ${ }^{31}$ What could justify such interference?

What can justify it is precisely the radical failure of the local state to discharge its duty to hold the hostis generis humani to account. If the state with primary jurisdiction 'is unwilling or unable genuinely to carry out the investigation or prosecution' of such crimes (typically because their perpetrators are state agents), it has not just failed in its duty to protect its citizens against such crimes and to call their perpetrators to account: it has thus also rendered itself complicit in those crimes, and set itself against the polity whose institutional embodiment it is supposed to be. The ICC then speaks in the name of the community of nations, on behalf of the citizens of the nation in which the crime was committed, whose own state apparatus has failed them through its unwillingness or inability to prosecute the crime. The community of nations, whose members are taken to share an understanding of their duties and responsibilities towards their own citizens, is (or claims to be) entitled to step in if one of its members radically fails to discharge those duties. It does not step in to discharge that precise duty itself, for it cannot do so: the ICC cannot hold the hostis generis humani to account to his own fellow citizens, or by doing so restore the civil order that he disrupted (analogously, if the polity steps in when parents radically fail to discharge their duties towards their children, it cannot step in to provide the parental care that the parents failed to provide). But it can aim to provide a second-best substitute (analogously, the polity can provide a kind of care for the child whose parents failed her): for it can hold the hostis generis humani to account, to a community of nations that does have a proper interest in the matter and that can thus claim the

30 See Christopher Wellman, 'Piercing Sovereignty,' in Philosophical Foundations of Criminal Law, eds. Antony Duff and Stuart P. Green (Oxford: Oxford University Press, 2010), 461.

31 This is oversimplified, since cases may (but need not) be referred to the ICC by the state party that has primary jurisdiction over them (Rome Statute, Arts. 13-14), and more crucially since the ICC has authority only in relation to states that are parties to the Statute: but in becoming a party to the Statute, a state accepts the possibility of such interference in its sovereignty. 
standing to do so; for the community of nations has a proper interest in whether its members discharge their responsibilities as nations - as polities.

I am by no means confident that the kind of account towards which I have gestured here is a viable one: viable not so much as an interpretation of the claims actually made on behalf of the ICC, but as an account of what could give its jurisdiction a plausible normative grounding - and perhaps therefore as a rational reconstruction of some of its purported aims and claims. I do think that, whilst Luban provides a very plausible account of the distinctive character of crimes against humanity, and thus of the hostis generis humani as one who commits such crimes; and whilst he shows that we need not see the hostis generis humani as one who has excluded himself, or whom we may or should exclude, from human community and from the reach of human law: he has not yet provided an entirely convincing account of the community by and to whom the hostis generis humani can be called to answer in a tribunal like the ICC, since a moral community of humanity is not really apt to play that role. I have suggested that we can find an appropriate community in the community of nations that comes together to form a United Nations; but that suggestion still needs a lot more work. 